IRSTI 82.33.17

UDC 338.242.2

Z.R. KARBETOVA, ${ }^{1}$

c.t.s., professor.

A.A. ZHAKUPOV,

$\mathrm{PhD}$, associate professor.

SH.R. KARBETOVA, ${ }^{2}$

c.e.s., associate professor.

Z.Y. BEYSEKOVA, ${ }^{2}$

c.e.s., associate professor.

Kazakh University of Technology and Business. ${ }^{1}$

Kazakh Academy of Labor and Social Relations ${ }^{2}$

\title{
FEATURES OF CORPORATE CULTURE INFLUENCE ON ORGANIZATION EFFICIENCY
}

\begin{abstract}
This article shows relationship of corporate culture influence on organization efficiency and relevance of this topic, which is of great interest due to lack of development of this issue. The study of corporate culture of organization is due to qualitative changes in approaches regarding the influence of corporate culture on organization effectiveness. Organization efficiency requires that its culture, strategy, environment and technology are interconnected and aligned with each other. There are two ways that corporate culture can influence the life of an organization. Firstly, culture and behavior mutually influence each other. Secondly, culture affects not so much what people do, but how they do it. In process of formation and implementation of corporate culture, in our opinion, factors such as leader's culture and national culture, organization's mission, industry, external environment, structure and size of organization, etc. should be taken into account. The ability to solve goals and objectives set for corporate culture determines its effectiveness. In the study, authors revealed theoretical foundations of formation of corporate culture and its content, examined methods of studying corporate culture of organization and identified best methods for developing corporate culture of foreign countries. As a result of analysis and sociological research to improve corporate culture of BadysSidi Company LLP, authors developed recommendations for further development. Corporate culture requires ability to manage it in order to make changes effective. Effective management requires availability of appropriate management tools and real assessment of state and level of development of corporate culture.
\end{abstract}

Key words: corporate culture, efficiency, analysis, strategy, optimal methods, problems, theoretical foundations, national culture, manager's mission.

Corporate culture is a powerful strategic management and development tool that allows employees to be oriented towards common goals, manifestation of initiative, personal effectiveness and productive interaction. A correct assessment of the corporate culture of the enterprise will allow us to develop optimal approaches to management and select the appropriate mechanisms for transforming the corporate culture, and as a result improves the quality of products and the competitiveness of the enterprise [1]. The impact on the activities of the organization of corporate culture is huge, so its study is relevant.

The purpose of this research work is to substantiate the role of corporate culture as a decisive factor in increasing the effectiveness of the organization and improving the mechanism of formation and management of corporate culture on the example of BadysSidi Company LLP. The purpose of the study involves solving the following problems:

- consider the theoretical foundations of the formation of corporate culture;

- identify the best methods for the development of corporate culture of foreign countries and compare the experience of their application in the Republic of Kazakhstan;

- to analyze the formation of corporate culture on the example of the analyzed company;

- develop basic recommendations for improving corporate culture in BadysSidi Company LLP.

In studying the influence of corporate culture on the effectiveness of the organization, various methods were used: abstract-logical, normative; economic-mathematical and graphic, a system of comparisons and analysis of modern practice of forming corporate culture and methods of sociological research [2]. 
Modern managers are well aware of the role of corporate culture in competition and the need to change it in connection with the implementation of new strategies. However, many companies have a poor understanding of the practical aspect of managing organizational culture, i.e. they don't understand how to apply corporate culture in practice to achieve strategic goals, increase competitiveness, and develop leadership potential [3].

Currently, in Kazakhstan, when considering the corporate management of large companies in the real sector of the economy, there are conditionally several types of corporate culture. The first type includes companies using traditional methods of organizing personnel. These include all state monopolistic companies, national companies and companies with one hundred percent state participation (KTZ, Kazakhtelecom, KEGOK, Kazatomprom).

The second type of companies is foreign and international companies, their branches and representative offices opened in Kazakhstan, for example, Philip Morris Kazakhstan, Gallagher Kazakhstan, Tengizchevroil, Parker Drilling Company, Petro Kazakhstan, etc. This type of company practices a modern corporate culture system.

With a competent approach, culture can become a powerful motivator and tool to achieve the goals of the organization. The corporate motivation system becomes part of the functioning of the organization, which has a stimulating effect on employees in accordance with the norms and values that form its basis and is formed on the basis of the existing corporate culture [4].

The content of culture affects the content of communication. In some organizations, openness in communication is valued, while in others it is the other way around. A strong culture makes the identification and feelings of the individual with respect to the organization strong.

Organizational culture can benefit the enterprise, create a favorable internal environment and introduce a new external environment. But it can impede the strategic development of the enterprise [5].

There are many diagnostic methods for corporate culture [6]. In our study, we used the methodology of K. Cameron and R. Quinn, the essence of which is that on the basis of various criteria, we identify the main types of corporate cultures and correlate the culture of our organization. C. Cameron and R. Quinn examined the performance indicators of large companies in two dimensions. The first dimension separates performance criteria, which emphasize flexibility, discretion, and dynamism, from criteria that emphasize stability, order, and control. The second dimension separates performance criteria that emphasize internal orientation, integration, and unity from those associated with external orientation, differentiation, and rivalry. Both of these dimensions form four squares. These four groups of criteria determine the core values by which a judgment is made about the organization [7].

The measurement of competing values in a model is done using "scaled" questionnaires. Six cultural parameters are evaluated at their current and desired level. In this questionnaire, the parameter "A" corresponds to the clan organizational culture, "B" - adhocratic, "C" - market, " $D$ " - hierarchical. In accordance with the data obtained, two profiles of the organization are drawn - the existing culture and the desired one.

Comparison of diagrams of various parameters for the same culture or common profiles for different departments allows us to conclude that the company is culturally or inconsistently. The equilibrium state of various aspects of culture in various divisions leads to an increase in company cohesion and the creation of a favorable social climate for managerial decision-making.

Another technique used to study the influence of corporate culture on the effectiveness of an organization is a survey of express diagnostics of corporate culture. This test made it possible to assess the direct impact factors, where a total score of over 175 points indicates a positive direction of corporate culture and its impact on the organization

To diagnose the existing corporate culture of BadysSidi Company LLP and determine its type, employees were offered a questionnaire by K. Cameron and R. Quinn and a small questionnaire for rapid diagnosis of corporate culture. A total of 33 people participated in the survey, of which $42 \%$ were women and 58\% are men. The main age structure of the organization is people aged 20 to 30 years, which suggests that management attracts and in every possible way promotes the development of young employees, seeing in them an active and proactive basis for panii [8]. The experience of employees plays a significant role in achieving the effectiveness of the organization. The average 
work experience in the company is 7 years, which, with a general 12th history, indicates the stability of the number of personnel and the values and traditions that exist in the organization.

The level of education in the company is quite high, where $65 \%$ of employees have a diploma of higher education.

The first questionnaire evaluated six cultural parameters at their current and desired level: the most important characteristics of the organization, leadership and leadership style, management of employees, the essence of the organization, strategic orientation, and success criteria. In the questionnaire, the parameter " $\mathrm{A}$ " corresponds to the clan culture, "B" - adhocratic, "C" - market, "D" - hierarchical.

We evaluated and analyzed the existing corporate culture, then analyzed its desirable type, on the basis of which a comparative characteristic of corporate culture was compiled [9].

Analyzing the existing, market type of culture in the BadysSidi Company LLP, we can conclude that the organization's culture is positive, as it contributes to the effective solution of problems and productivity growth, stimulates the effectiveness of the enterprise and its development, is a source of competent management decisions.

We have determined the effectiveness of the main components of corporate culture. Average scores for each of the criteria fell between 7-9 points, which is a high level of corporate culture and indicates its high level. Analyzing the factors among themselves, one can notice that they are all equally well developed and are at approximately the same level, which indicates their effective interaction and high-quality implementation.

This testing makes it possible to evaluate these factors directly, where a total score of over 175 points indicates a positive direction of corporate culture. The maximum value is 290 points, according to the survey, this indicator amounted to 234 points, which tells us about the overall high rate of corporate culture of BadysSidi Company LLP. Thus, the corporate culture of the company operates efficiently. There is a clear strategy and mission of the organization.

At the present stage, when BadysSidi Company LLP has achieved its goals and objectives, it has reached a new level of its development, dedication to experimentation and innovation should become the connecting essence of the organization. For this organization, it is necessary to promote the personal initiative and freedom of its employees. Thus, the main thing is to gradually change and optimize individual functions and units, turning changes into a continuous development process.

Based on the analysis of the corporate culture of Badys Sit Company LLP, we proposed a number of recommendations for improving the culture of the corporation and introducing its new type, the type of adhocracy, which is characterized by a more flexible management system and an entrepreneurial and innovative climate in the organization. Thus, when management takes action to implement these recommendations, it will be one of the first steps towards improving the corporate culture and using it to further increase the effectiveness of the organization.

The study allowed us to draw the following conclusions.

1. The work reveals the theoretical foundations and methods of studying the corporate culture of the organization, its elements, functions.

2. Diagnostics and assessment of corporate culture in accordance with the requirements of strategic management. The necessity of conducting research in the field of corporate governance and the influence of corporate culture on the effectiveness of the organization's functioning is proved.

3. The type of culture of the organization was determined, and its desirable development through questionnaires.

4. Recommendations on the implementation and formation of corporate culture at the enterprise are proposed, which may have practical significance and value in the management system of any organization.

Thus, corporate culture is a tool in the hands of a manager, with which you can lead the company to success, prosperity and stability, but with inappropriate or inappropriate use, directly opposite results are possible. Therefore, the corporate culture should be adequate to modern requirements dictated by economic and technological development, the specifics of Kazakhstani legislation and mentality, as well as the specifics of a particular organization, to contribute to the achievement of goals and increase the efficiency of the company as a whole. 


\title{
LIST OF LITERATURE
}

1 Персикова Т. Корпоративная культура: учебник. - М.: Логос, 2015. - 112 с.

2 Добреньков В.И. Альберт Кравченко. Методы социологического исследования. - М.: ИНФРА-М, 2017. -768 c.

3 Колесников А.В. Корпоративная культура. - М.: Издательство «Юрайт», 2017. - 167 с.

4 Ветошкина Т. Влияние корпоративной культуры на мотивацию персонала // Кадровик. Кадровый менеджмент. - 2008. - № 9. - С. 22-23.

5 Мэнцин М. Совершенствование организационной культуры на предприятии ООО «САНЬЕ» [PDF]. Untitledvital.lib.tsu.ru > access > services > Download > vital:7136 > SOURCE01. - M., 2018.

6 Столбова Д.В., Щеткина В.Н., Варцаба Ф.Н. Формирование организационной культуры в реализации стратегии компании // Молодой ученый. - 2016. - № 25. - С. 399-403.

7 Пак В.Д., Нужина Н.И. Основные типологии организационной культуры: https://research-journal. org > osnovnye-tipologii-organizacionnoj-kultury. 2014.

8 Данные социологического исследования ТОО «Бадыс Сиди компани»: как составить программу социологического исследования и план его проведения? Как проводится сбор социологической информации, метод опроса, требования к формулировке вопросов и т.д.: www.hse.ru > data > 2013/09/06 > Prikl_Soc_full, 6 сент. 2013 г.

$\overline{9}$ Диагностика и изменение организационной культуры (по методике OCAI): https://studfile.net > preview 12 марта 2016.

3.P. КАРБЕТОВА, ${ }^{1}$

Т.Ғ.К., профессор.

А.А. ЖАКУПОВ, ${ }^{1}$

$\mathrm{PhD}$, доцент.

Ш.Р. КАРБЕТОВА, ${ }^{2}$

э.Ғ.к., дОцент.

Ж.Ы. БЕЙСЕКОВА, ${ }^{2}$

э.Ғ.К., доцент.

Қазақ технология және бизнес университеті. ${ }^{1}$

Қазақ еңбек және әлеуметтік қатынастар академиясы ${ }^{2}$

\section{ҰЙЫМНЫН ТИІМДІЛІГІНЕ КОРПОРАТИВТІК МӘДЕНИЕТТІҢ ӘСЕР ЕТУ ЕРЕКШЕЛІКТЕРІ}

\begin{abstract}
Андатпа
Мақалада корпоративтік мәдениеттің ұйымның тиімділігіне әсері мен осы тақырыптың өзектілігі болмайтындықтан үлкен қызығушылық тудыратын осы тақырыптың өзектілігі көрсетілген. Ұйымның корпоративті мәдениетін зерттеу ұйымның тиімділігіне корпоративтік мәдениеттің әсеріне қатысты көзқарастардың сапалы өзгеруіне байланысты. Ұйымның тиімділігі оның мәдениеті, стратегиясы, қоршаған ортасы мен технологиясы бір-бірімен байланысты және бір-бірімен сәйкес келуін талап етеді. Корпоративтік мәдениеттің ұйым өміріне әсер етудің екі жолы бар. Біріншіден, мәдениет пен мінез-құлық бір-біріне әсер етеді. Екіншіден, мәдениет адамдардың іс-әрекетіне ғана емес, оны қалай жасайтындығына да әсер етеді. Корпоративті мәдениетті қалыптастыру және жүзеге асыру процесінде, біздің ойымызша, көшбасшы мәдениеті мен ұлттық мәдениеті, ұйымның миссиясы, саласы, сыртқы ортасы, ұйымның құрылымы мен мөлшері және т.б. сияқты факторларды ескеру қажет. Корпоративтік мәдениеттің алдына қойылған мақсаттар мен міндеттерді шеше білу оның тиімділігін анықтайды. Зерттеуде авторлар корпоративті мәдениеттің қалыптасуының теориялық негіздерін және оның мазмұнын ашты, ұйымның корпоративтік мәдениетін, оның элементтерін, функцияларын зерттеудің әдістерін зерттеді және шет мемлекеттердің корпоративті мәдениетін дамытудың ең жақсы әдістерін анықтады. Корпоративті мәдениеттің қалыптасуын талдау, сонымен қатар, талданатын компанияның мысалын қолдану арқылы жүргізілді және «Бадыс Сиди компания» ЖШС-де корпоративті мәдениетті жақсарту бойынша негізгі ұсыныстар жасалды. Корпоративтік мәдениет өзгерістерді тиімді ету үшін оны басқару қабілеттілігін талап етеді. Оны тиімді басқару тиісті басқару құралдарының болуын және корпоративтік мәдениеттің жай-күйі мен даму деңгейін нақты бағалауды талап етеді.
\end{abstract}

Тірек сөздер: корпоративті мәдениет, тиімділік, талдау, стратегия, оңтайлы әдістер, проблемалар, теориялық негіздер, ұлттық мәдениет, басшының миссиясы. 
3.P. КАРБЕТОВА, ${ }^{1}$ к.т.Н., профессор.

А.А. ЖАКУПОВ, ${ }^{1}$

$\mathrm{PhD}$, доцент.

II.P. КАРБЕТОВА,

к.э.н., доцент.

Ж.Ы. БЕЙСЕКОВА,

к.э.Н., доцент.

Казахский университет технологии и бизнеса. ${ }^{1}$ Казахская академия труда и социальных отношений ${ }^{2}$

\title{
ОСОБЕННОСТИ ВЛИЯНИЯ КОРПОРАТИВНОЙ КУЛЬТУРЫ НА ЭФФЕКТИВНОСТЬ ДЕЯТЕЛЬНОСТИ ОРГАНИЗАЦИИ
}

\begin{abstract}
Аннотация
В статье показана взаимосвязь влияния корпоративной культуры на эффективность деятельности организации и актуальность данной темы, которая представляет большой интерес из-за недостаточной разработки данного вопроса. Изучение корпоративной культуры организации обусловлено качественными изменениями в подходах, касающихся влияния корпоративной культуры на эффективность деятельности организации. Эффективность деятельности организации требует, чтобы ее культура, стратегия, окружение и технология были взаимосвязаны и приведены в соответствие друг с другом. Существуют два пути влияния корпоративной культуры на жизнь организации: первый - культура и поведение взаимно влияют друг на друга; второй - культура влияет не столько на то, что люди делают, сколько на то, как они это делают. В процессе формирования и реализации корпоративной культуры, по нашему мнению, следует учитывать такие факторы, как культура руководителя и национальная культура, миссия организации, отрасль, внешняя среда, структура и размер организации и др. Способность разрешать поставленные перед корпоративной культурой цели и задачи определяют ее эффективность. В исследовании авторами раскрыты теоретические основы формирования корпоративной культуры и ее содержание, рассмотрены методики изучения корпоративной культуры организации и выявлены оптимальные методы развития корпоративной культуры зарубежных стран. В результате проведенного анализа и социологических исследований по совершенствованию корпоративной культуры ТОО «Бадыс Сиди компании» авторами разработаны рекомендации по дальнейшему его развитию. Корпоративная культура требует умения управлять ею в целях эффективности проводимых изменений. Эффективное управление ею предполагает наличие соответствующих инструментов управления и реальной оценки состояния и уровня развития корпоративной культуры.
\end{abstract}

Ключевые слова: корпоративная культура, эффективность, анализ, стратегия, оптимальные методы, проблемы, теоретические основы, национальная культура, миссия руководителя. 